\title{
Enhanced Anaerobic Digestion by Stimulating DIET Reaction
}

\author{
Alsayed Mostafa ${ }^{1} \mathbb{D}$, Seongwon Im $^{1}$, Young-Chae Song ${ }^{2} \mathbb{D}$, Yongtae Ahn ${ }^{3}$ and \\ Dong-Hoon Kim ${ }^{1, *}$ \\ 1 Department of Civil Engineering, Inha University, 100 Inha-ro, Nam-gu, Incheon 22212, Korea; \\ ama_mostafa@ymail.com (A.M.); deback3838@naver.com (S.I.) \\ 2 Department of Environmental Engineering, Korea Maritime and Ocean University, Busan 49112, Korea; \\ soyc@kmou.ac.kr \\ 3 Department of Energy Engineering, Gyeongnam National University of Science and Technology, \\ Dongjin-ro 33, Jinju 52725, Korea; ytahn79@gmail.com \\ * Correspondence: dhkim77@inha.ac.kr
}

Received: 11 March 2020; Accepted: 30 March 2020; Published: 3 April 2020

Abstract: Since the observation of direct interspecies electron transfer (DIET) in anaerobic mixed cultures in 2010s, the topic "DIET-stimulation" has been the main route to enhance the performance of anaerobic digestion (AD) under harsh conditions, such as high organic loading rate (OLR) and the toxicants' presence. In this review article, we tried to answer three main questions: (i) What are the merits and strategies for DIET stimulation? (ii) What are the consequences of stimulation? (iii) What is the mechanism of action behind the impact of this stimulation? Therefore, we introduced DIET history and recent relevant findings with a focus on the theoretical advantages. Then, we reviewed the most recent articles by categorizing how DIET reaction was stimulated by adding conductive material $(\mathrm{CM})$ and/or applying external voltage (EV). The emphasis was made on the enhanced performance (yield and/or production rate), CM type, applied EV, and mechanism of action for each stimulation strategy. In addition, we explained DIET-caused changes in microbial community structure. Finally, future perspectives and practical limitations/chances were explored in detail. We expect this review article will provide a better understanding for DIET pathway in AD and encourage further research development in a right direction.

Keywords: direct interspecies electron transfer (DIET); conductive material (CM); external voltage (EV); microbial community change; anaerobic digestion

\section{Introduction}

Anaerobic digestion (AD) is a traditional biological process utilized for treating various organic wastes including wastewater and complex solid wastes. Via AD, organic matters are converted to biogas, rich in methane $\left(\mathrm{CH}_{4}\right)$, while nutrients-rich residues suitable for high-quality compost are generated as byproduct [1-3]. AD process consists of up to four consecutive steps, i.e., hydrolysis, acidogenesis, acetogenesis, and methanogenesis, in which the rate-limiting step can be different depending on the type of treated feedstock [4]. However, the syntrophic acetogenesis was often considered as a bottleneck that is highly governing the whole rate of AD process [5,6]. Syntrophic acetogens convert $\mathrm{C}_{2}-\mathrm{C}_{6}$ organic acids/alcohols to electron donors of low-molecular weight, mainly $\mathrm{H}_{2}$ and acetic acid, which would be consumed by methanogens. This is a well-known indirect interspecies electron transfer (IIET) route, and many attempts were made to enhance this reaction. In particular, the importance of keeping low $\mathrm{H}_{2}$ partial pressure for acquiring stable IIET was addressed in many studies [7-9]. However, a new route, transferring electrons directly between acetogens or acidogens to methanogens, called direct interspecies electron transfer (DIET), was recently introduced (Figure 1). 


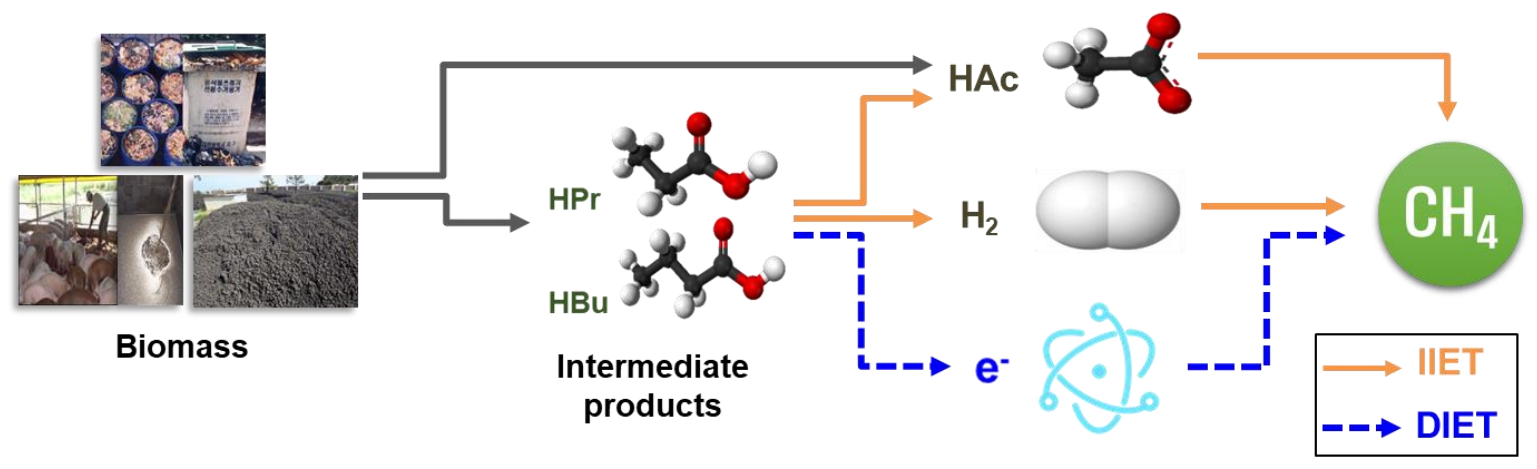

Figure 1. Indirect interspecies electron transfer (IIET) using acetate (HAc) and/or hydrogen $\left(\mathrm{H}_{2}\right)$ vs. direct interspecies electron transfer (DIET) in anaerobic digestion.

The first observation of DIET was done by Summers et al. [10], between two Geobacter sp. (G. metallireducens and G. sulfurreducens) in metabolizing ethanol. Geobacter is a well-known anaerobic metal oxidizer and can produce electrically conductive pili (e-pili), which can exchange electrons among different cells [11]. Later on, to our knowledge, the first clear evidence of DIET for $\mathrm{CH}_{4}$ production was observed by Rotaru et al. [12]. When G. metallireducens was cocultured with Methanosaeta harundinacea

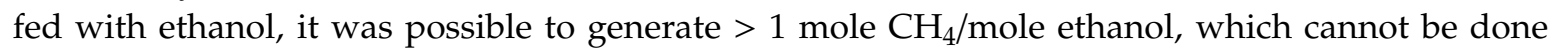
theoretically. From one mole of ethanol, G. metallireducens can generate 1 mole of acetate with 2 moles of $\mathrm{H}_{2}$. Methanosaeta harundinacea cannot metabolize $\mathrm{H}_{2}$, and thus, the theoretical maximum $\mathrm{CH}_{4}$ yield is 1 mole $\mathrm{CH}_{4} /$ mole ethanol. From this result, the authors indicated DIET between two species, which was further confirmed by metatranscriptomic analysis. Thereafter, not only Geobacter, but the presence of many other electro-active bacteria (EAB) was detected in AD broth, and the research to stimulate DIET reaction is extensively going on [13-16].

Through the studies of last ten years, it was found that DIET reaction could be stimulated either by the supplementation of a conductive material (CM) and/or applying external voltage (EV) (Figure 2) [17-20]. Basically, EAB can oxidize organics, and then the released electrons are directly transferred through the extracellular cytochromes or the e-pili of EAB to methanogens, which reduce $\mathrm{CO}_{2}$ into $\mathrm{CH}_{4}$ [12]. Almost all of the DIET-related studies agreed that e-pili are composed of PilA protein [21-24]. Supplementing CM, specifically magnetite, could interestingly mediate the electron transfer among cells through substituting the pilus-associated cytochrome OmcS that are commonly found in G. sulfurreducens [25]. Li et al. [26] observed an increase in electron transfer rate from $0.0017 \pm 0.0003$ to $0.0056 \pm 0.0015 \mathrm{~s}^{-1}$, as a result of carbon cloth supplementation. Additionally, DIET could be stimulated through the establishment of two electrodes inside AD reactor, under slight EV with/without the presence of CM [3,27-29]. Such systems were called as bioelectrochemical systems merged with anaerobic digestion (BES-AD), which were initially applied for hydrogen generation [30-33]. However, the produced hydrogen was easily further converted to $\mathrm{CH}_{4}$ on the cathode, while the overall $\mathrm{CH}_{4}$ production rate was increased. The interesting thing found here was that the amounts of $\mathrm{CH}_{4}$ generated through the electrodes in BES-AD systems were limited, while the majority of $\mathrm{CH}_{4}$ production was assigned to the bulk of the broth, indicating active DIET reaction happening in the bulk [3,27-29].

Recent DIET-related review articles have mainly focused on the evidences of DIET and the addition of CM for stimulating DIET [34-37]; while the application of EV for stimulating DIET and corresponding microbial community change were not addressed. In this review, we are combing various points regarding DIET, i.e., DIET-caused thermodynamic favorability, recent researches that employed CM and/or EV for DIET stimulation, DIET-driven microbial community change, and future insights for DIET-related hot topics. Further, herein, we are giving a special focus for the contradictory results and debatable points that were found in recent DIET-related research articles. This review is 
expected to draw a panoramic understanding for various aspects related to DIET and figure out the weakness/challenging points in our knowledge about DIET.

(a)

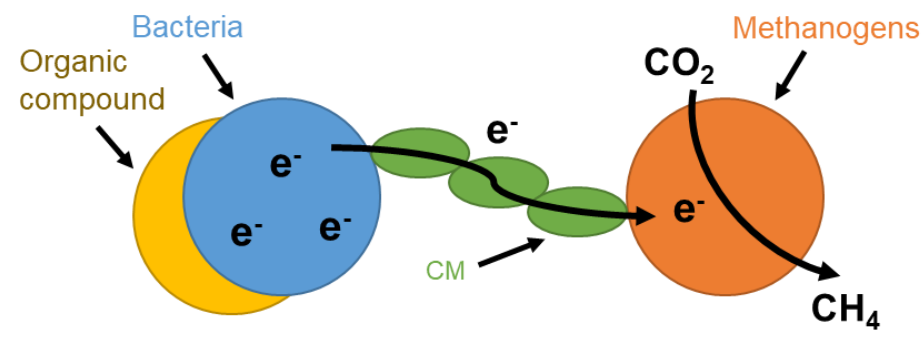

(b)

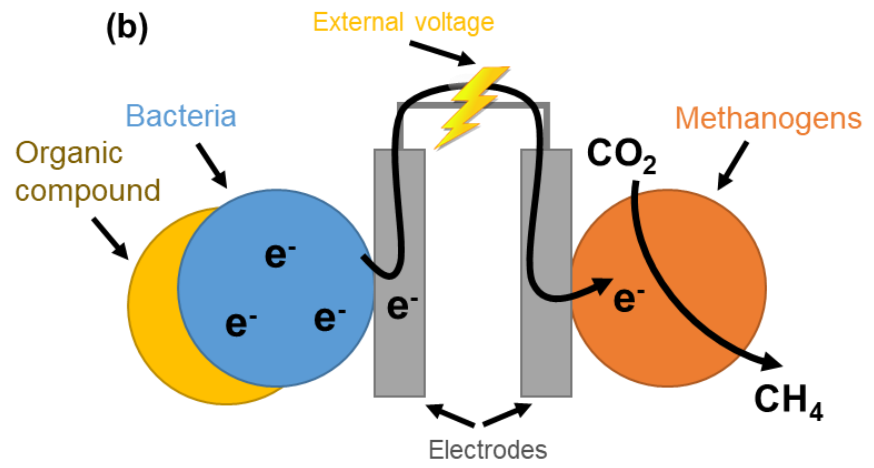

Figure 2. DIET stimulation mechanisms through (a) supplementation of conductive material (CM) and (b) applying external voltage (EV).

\section{DIET-Caused Theoretical Advantages}

From the thermodynamic perspective, it was basically expected that DIET can provide more energy benefits for the syntrophic partners than that secured by IIET. This is because in the case of DIET, there is no need for the generation and diffusion of metabolites, where these reactions consume energy [38]. In addition, under such conditions, there is no potential problems from accumulation of $\mathrm{H}_{2}$, and as a result, faster electron transfer is expected [39]. As clearly shown in Table 1, DIET can provide a more thermodynamically favorable route for producing $\mathrm{CH}_{4}$ from simple, toxic, and complex substrates, comparted to IIET. The reason for this difference is that Gibbs free energy of $\mathrm{H}_{2}$ is zero, while $\mathrm{H}^{+}$has Gibbs free energy of $-39.8 \mathrm{~kJ} / \mathrm{mol}$ at $\mathrm{pH} 7$ [40]. Therefore, DIET is advantageous for gaining more energy, facilitating cell growth and finally enhancing reaction rate. In addition, recent studies could calculate the external electron transfer rates per cell pair (cp) values, through mathematical modeling, which were $44.9 \times 10^{3}$ and $5.24 \times 10^{3} \mathrm{e}^{-} \mathrm{cp}^{-1} \mathrm{~s}^{-1}$ for DIET and $\mathrm{H}_{2}$-based IIET, respectively [12,41,42].

Table 1. Gibbs free energies for various reactions, under indirect interspecies electron transfer (IIET) and direct interspecies electron transfer (DIET) conditions.

\begin{tabular}{|c|c|c|c|c|c|}
\hline Reaction & Type of Reaction & Equation & & $\Delta \mathrm{G}^{0}(\mathrm{~kJ} / \mathrm{mol})$ & Reference \\
\hline \multirow{2}{*}{ Ethanol to $\mathrm{CH}_{4}$} & IIET & $\mathrm{CH}_{3} \mathrm{CH}_{2} \mathrm{OH}+\mathrm{H}_{2} \mathrm{O}$ & $\rightarrow \mathrm{CH}_{3} \mathrm{COO}^{-}+\mathrm{H}^{+}+2 \mathrm{H}_{2}$ & +9.7 & [40] \\
\hline & DIET & $\mathrm{CH}_{3} \mathrm{CH}_{2} \mathrm{OH}+\mathrm{H}_{2} \mathrm{O}$ & $\rightarrow \mathrm{CH}_{3} \mathrm{COO}^{-}+5 \mathrm{H}^{+}+4 \mathrm{e}^{-}$ & -149.6 & {$[40]$} \\
\hline \multirow{2}{*}{ Propionate to $\mathrm{CH}_{4}$} & IIET & $\mathrm{CH}_{3} \mathrm{CH}_{2} \mathrm{COO}^{-}+3 \mathrm{H}_{2} \mathrm{O}$ & $\rightarrow \mathrm{CH}_{3} \mathrm{COO}^{-}+\mathrm{HCO}_{3}^{-}+\mathrm{H}^{+}+3 \mathrm{H}_{2}$ & +76.5 & [40] \\
\hline & DIET & $\mathrm{CH}_{3} \mathrm{CH}_{2} \mathrm{COO}^{-}+3 \mathrm{H}_{2} \mathrm{O}$ & $\rightarrow \mathrm{CH}_{3} \mathrm{COO}^{-}+\mathrm{HCO}_{3}^{-}+7 \mathrm{H}^{+}+6 \mathrm{e}^{-}$ & -162.5 & [40] \\
\hline \multirow{2}{*}{$\mathrm{CH}_{4}$ oxidation } & IIET & $\mathrm{CH}_{4}+3 \mathrm{H}_{2} \mathrm{O}$ & $\rightarrow \mathrm{HCO}_{3}^{-}+\mathrm{H}^{+}+4 \mathrm{H}_{2}$ & +135.6 & [40] \\
\hline & DIET & $\mathrm{CH}_{4}+3 \mathrm{H}_{2} \mathrm{O}$ & $\rightarrow \mathrm{HCO}_{3}^{-}+9 \mathrm{H}^{+}+8 \mathrm{e}^{-}$ & -183.1 & [40] \\
\hline \multirow{2}{*}{ Phenol to $\mathrm{CH}_{4}$} & IIET & $\mathrm{C}_{6} \mathrm{H}_{5} \mathrm{OH}+5 \mathrm{H}_{2} \mathrm{O}$ & $\rightarrow 3 \mathrm{C}_{2} \mathrm{H}_{4} \mathrm{O}_{2}+2 \mathrm{H}_{2}$ & +150.5 & {$[29]$} \\
\hline & DIET & $\mathrm{C}_{6} \mathrm{H}_{5} \mathrm{OH}+5 \mathrm{H}_{2} \mathrm{O}$ & $\rightarrow 3 \mathrm{C}_{2} \mathrm{H}_{4} \mathrm{O}_{2}+4 \mathrm{H}^{+}+4 \mathrm{e}^{-}$ & -9.0 & [29] \\
\hline \multirow{2}{*}{ Oleate to $\mathrm{CH}_{4}$} & IIET & $\mathrm{C}_{18} \mathrm{H}_{33} \mathrm{O}_{2}^{-}+16 \mathrm{H}_{2} \mathrm{O}$ & $\rightarrow 9 \mathrm{C}_{2} \mathrm{H}_{3} \mathrm{O}_{2}^{-}+15 \mathrm{H}_{2}+8 \mathrm{H}^{+}$ & +340.9 & [43] \\
\hline & DIET & $\mathrm{C}_{18} \mathrm{H}_{33} \mathrm{O}_{2}^{-}+16 \mathrm{H}_{2} \mathrm{O}$ & $\rightarrow 9 \mathrm{C}_{2} \mathrm{H}_{3} \mathrm{O}_{2}^{-}+38 \mathrm{H}^{+}+30 \mathrm{e}^{-}$ & -641.1 & [43] \\
\hline
\end{tabular}

From energetic standpoint, some energy loss, however, was observed in the case of DIET occurrence; this was ascribed to the activation energy needed for electron donating and accepting 
redox cofactors (such as cytochromes) in order to transfer electrons [41]. It is worthy to highlight that the aforementioned electron transfer rate constants that were evaluated by Storck's group [41] were based on the respiration of Shewanella sp. on the electrodes. Considering that this Shewanella sp. has a limited electrical current density, and the transfer rate has high impact upon energy loss [44], it can be concluded that the above-stated values might be lower than the real values associated with electron transfer under DIET-stimulated conditions. Future advanced experiments and mathematical models are needed in order to accurately evaluate electron transfer constants for DIET and IIET.

The dominance of DIET over other potential syntrophic metabolism routes might happen as a response for the broth reactions. In other words, DIET can be a more favored route for microorganism in order to encounter environmental conditions [38]. For instance, when overall energy yield from a certain reaction is limited, the consumption of energy for generating metabolite, as electron shuttles, can be unfavored; instead, DIET in such case can be the optimal choice for energy saving $[10,38]$. For example, DIET could dominate over other IIET routes, when the system was subjected to acidic inhibition [45,46], toxic substrate [29,43], sulfate-rich wastewater [47], or ammonia containing wastewater [48].

So far, investigating the accurate number of electrons released from one organism and received by another one is still difficult, especially in the case of mixed cultures; therefore, the determination of the accurate energy gain for each microorganism is still limited. The determination of in-situ free energy potential, associated with DIET, is required for evaluating the portion of free energy that are available/consumed during DIET.

\section{CM as a Tool for DIET Pathway Stimulation}

Based on their capability for DIET stimulation, CM are widely utilized for enhancing the efficiency and stability of $\mathrm{CH}_{4}$ production [42,49]. Utilized $\mathrm{CM}$ can be classified into carbon-based conductive materials (CBCM) and iron-based conductive materials (IBCM). [49]. CM could compensate the lack of vital cell components, needed for completion of DIET, such as pili and c-type cytochrome [50-52]. In ethanol-fed methanogenic co-culture that consisted of Methanosarcina barkeri and G. sulfurreducens, which had deficiency of pili and pili-associated cytochrome OmcS, no $\mathrm{CH}_{4}$ could be produced unless $\mathrm{CM}$, i.e., biochar, was supplemented [52]. Chen's group inferred that the presence of biochar enabled $86 \%$ of the electrons produced during ethanol oxidation to be utilized for $\mathrm{CH}_{4}$ generation; while in the absence of biochar, neither ethanol oxidation nor $\mathrm{CH}_{4}$ generation was observed [52]. In addition, when the pilin-associated c-type cytochrome (OmcS), required for DIET, was not available in Geobacter species, magnetite could compensate such lack, and reduce the need for cell to produce OmcS [25]. Similarly, when PilA gene was deleted or yielded very limited pili, Geobacter strains grew and made co-cultures in the presence of granular activated carbon (GAC); this observation would never happen without GAC role [53,54].

Table 2 shows the positive/negative impact of $\mathrm{CM}$ upon $\mathrm{CH}_{4}$ productivity for various wastes, treated in batch and continuous treatment systems, specifically up-flow anaerobic sludge blanket reactor (UASB). Generally, when CMs are added to batch tests, lag phase reduction and $\mathrm{CH}_{4}$ production rate increase could always be observed. However, the increase in $\mathrm{CH}_{4}$ production yield is not necessarily achieved [48,55-61]. Even, slight negative impact (-4\%, compared to control) upon cumulative $\mathrm{CH}_{4}$ production yield was observed by magnetite addition [62]. But, some reports showed that an increase in $\mathrm{CH}_{4}$ yield can be also observed after $\mathrm{CM}$ supplementation $[43,63]$. DIET-stimulated digesters were also able to sustain against the harsh operational conditions, e.g., accumulation of sulfate [47] or ammonia [48] or phenol [29]. Consequently, previous studies highlighted that complex substrates, e.g., $\operatorname{dog}$ food, sugar industrial wastewater, and leachate of municipal solid waste, can be effectively treated under DIET-stimulated conditions [49,64-67]. For justifying these results, authors referred that CM's presence might secure higher stability for the reactors and resulted in preventing the inhibition-causing problems. Further reason was the enrichment of either DIET-capable or incapable methanogens. In addition, some of those studies referred to the negativity of reaction Gibbs free energy value as a potential reason for enhanced performance. Finally, all these studies highlighted that DIET pathway 
saves energy, which is reflected on either overcoming the harsh conditions and/or generating higher volumes of $\mathrm{CH}_{4}$.

Table 2. Impact of various conductive material (CM) supplementation upon $\mathrm{CH}_{4}$ productivity.

\begin{tabular}{|c|c|c|c|c|c|c|}
\hline Conductive Material & Particle Size $(\mu \mathrm{m})$ & Concentration & Substrate & Operation & Improvement/Deterioration (\%) ${ }^{a}$ & Reference \\
\hline $\begin{array}{c}\text { Granular activated } \\
\text { carbon }\end{array}$ & $1220-1430$ & $10 \mathrm{~g} / \mathrm{L}$ & Glucose & Batch & $+168\left(\mathrm{CH}_{4}\right.$ production rate $)$ & [55] \\
\hline $\begin{array}{l}\text { Single wall carbon } \\
\text { nanotubes }\end{array}$ & $0.001-0.002$ & $1 \mathrm{~g} / \mathrm{L}$ & $\begin{array}{l}\text { Glucose } \\
\text { Sucrose }\end{array}$ & $\begin{array}{c}\text { Batch } \\
\text { Continuous }\end{array}$ & $\begin{array}{l}+92\left(\mathrm{CH}_{4} \text { production rate }\right) \\
--2\left(\mathrm{CH}_{4} \text { production }\right)\end{array}$ & $\begin{array}{l}{[55]} \\
{[63]}\end{array}$ \\
\hline Carbon nanotubes & $0.001-0.002$ & $5 \mathrm{~g} / \mathrm{L}$ & Glucose & Batch & $+2\left(\mathrm{CH}_{4}\right.$ yield $)$ & [56] \\
\hline Stainless steel & $500-2000$ & $26 \mathrm{~g} / \mathrm{L}$ & Sodium lactate & Continuous & $+8-+25\left(\mathrm{CH}_{4}\right.$ production $)$ & [47] \\
\hline Red mud & - & $20 \mathrm{~g} / \mathrm{L}$ & $\begin{array}{l}\text { Waste activated } \\
\text { sludge }\end{array}$ & Batch & $+36\left(\mathrm{CH}_{4}\right.$ production $)$ & [57] \\
\hline Ferric oxyhydroxide & - & $20 \mathrm{mM} \mathrm{Fe}$ & Whey & Batch & $+173\left(\mathrm{CH}_{4}\right.$ production Rate $)$ & [58] \\
\hline Ferrihydrite & - & $25 \mathrm{mM}$ & Acetate & Batch & $+15\left(\mathrm{CH}_{4}\right.$ production $)$ & [59] \\
\hline Magnetite & $0.05-0.70$ & $5-25 \mathrm{mM}$ & $\begin{array}{l}\text { Whey, propionate, } \\
\text { acetate, butyrate }\end{array}$ & Batch & $\begin{array}{c}+36-+203\left(\mathrm{CH}_{4} \text { production rate }\right) \\
-4-+44\left(\mathrm{CH}_{4} \text { production }\right)\end{array}$ & {$[48,58,60-62]$} \\
\hline
\end{tabular}

${ }^{a}$ Improvement/deterioration (\%), compared to control.

The different enhancement performances, implemented by CBCM and IBCM can be explained based on the difference in size and structure of such CM [68]. In specific, nano-sized IBCM are probably attached to the bacterial cells, since CM have smaller size than bacterial cells $[25,68]$. On the other hand, microbes can be efficiently attached to the surface of $\mathrm{CBCM}$, providing electron conduits for many microorganisms $[49,51,52]$. This strategy is more preferred for microbes, from metabolic standpoint, since there is no energy consumption for conductive pili synthesis [69]. This approach can be utilized for providing the efficiency of using the DIET-based syntrophy in anaerobic digestors with various configurations [70].

For interpreting the impact of $\mathrm{CM}$ upon methanogenesis, two important factors need to be considered, i.e., electrical conductivity and oxidation redox potential (ORP). Electrical conductivity of the utilized microbial consortia is supposed to be higher in $\mathrm{CM}$-amended reactors, compared to control $[16,53,55,67]$. Such increases can be related to the improved e-pili secretion, which is implemented by EAB that are enriched in the presence of CM $[67,71,72]$. Furthermore, ORP could be lowered down, to more negative values, as a result of $\mathrm{CM}$ addition [73]; this is beneficial for $\mathrm{CH}_{4}$ generation process, which need ORP of ( -200 to $-400 \mathrm{mv})$ in order to be successfully implemented [74]. From thermodynamic standpoint, the supplementation of $\mathrm{CM}$, which are featured of their negative redox potential, into AD broth can lead to directing reactions to DIET route [75]. In addition, it was found that the types and activities of e-pili and cytochromes, expressed from Geobacter and Pelobacter species for electron transfer, are different based on the surface potential, which is linked to the supplemented CM [76].

Notwithstanding, the enhancing impact, implemented by $\mathrm{CM}$, might be also assigned to the enhanced biomass colonization, since CM usually have large surface that is capable for cell adhesion, especially in the case of nano-sized materials [77-79]. This can justify the enhanced $\mathrm{CH}_{4}$ productivity, as CBCM are supplemented (Table 2). In case of IBCM, the electrical conductivity might have more remarkable impact than surface area $[43,80]$. Further study concluded that magnetite could play double role, i.e., (i) stimulating the up-regulated secretion of key enzymes that are involved in the substrate degradation and (ii) inducing the expression of DIET-related proteins [60]. Other studies confirmed that IBCM, specifically, magnetite and ferrihydrite, can act as oxidizing agents and enhance substrate degradation [20,81]. The latter role is not indeed related to DIET stimulation. Instead, it might be achieved at the expense of DIET stimulation, since IBCM are going to be consumed in such reactions instead of stimulating DIET. More research is needed in the future in order to highlight the relation between the enhancement, done by IBCM, and the characteristics of this CM, such as morphology and crystallinity. 


\section{Electrical Energy Input as Tool for DIET Pathway Stimulation}

In BES-AD, slight EV is applied in order to induce the vital reactions [82], and as a consequence, DIET reaction, and the growth of DIET-capable species are stimulated, directly transferring electrons from EAB species to anode surface [83]. Table 3 shows the impact of various EV upon $\mathrm{CH}_{4}$ from various wastes. Clearly, the slight EV application (-0.3--1.8 V vs. standard hydrogen electrode (SHE)) led to significant enhancements in $\mathrm{CH}_{4}$ production (20-1360\%). Previous studies showed that optimal range can be (-0.3--1.4 V vs. SHE) [84] or (-0.2--0.8 V vs. SHE) [85]. Variation in the optimal EV was found in the literature. For instance, EV of $-0.3 \mathrm{~V}$ vs. SHE was found to be effective for the treatment of phenol [29] and waste activated sludge (WAS) [86]; however, when EV was changed to $-0.6 \mathrm{~V}$ vs. SHE, no change in the enhanced performance was observed in the case of phenol, while negative impact was denoted in the case of WAS. Other studies showed different results while optimizing EV. In specific, EV ranges of (-0.5--1.5) and (-0.6--1.2 V vs. SHE) were tested for treating glucose and WAS, where optimal EV was found to be -1.0 and $-0.8 \mathrm{~V}$ vs. SHE, respectively $[87,88]$.

Table 3. Impact of various voltages' application upon $\mathrm{CH}_{4}$ productivity.

\begin{tabular}{|c|c|c|c|c|c|}
\hline Electrode Type & $\begin{array}{l}\text { Applied Voltage } \\
\text { (V vs. SHE) }\end{array}$ & $\begin{array}{c}\text { Electrode Surface } \\
\text { Area }\left(\mathrm{cm}^{2}\right)\end{array}$ & Substrate & $\begin{array}{c}\mathrm{CH}_{4} \text { Production } \\
\text { Improvement (\%) }\end{array}$ & Reference \\
\hline Carbon felt & -0.5 & 60 & $\begin{array}{l}\text { Waste activated sludge + } \\
\text { Molasses }\end{array}$ & 50 & [89] \\
\hline & -1.0 & $\mathrm{ND}^{\mathrm{a}}$ & Glucose & 36 & [84] \\
\hline Carbon fiber brush & -1.1 & $\mathrm{ND}^{\mathrm{a}}$ & Glucose & 30 & [88] \\
\hline Carbon nanotubes & -1.1 & $\mathrm{ND}^{\mathrm{a}}$ & Food waste & 20 & [90] \\
\hline $\begin{array}{l}\text { Carbon cloth + Cobalt } \\
\text { phosphorous catalyst }\end{array}$ & -0.8 & 12 & $\begin{array}{l}\text { Mixture of glucose, } \\
\text { starch granule, beef } \\
\text { extract, xylose, and } \\
\text { cellulose }\end{array}$ & 48 & [91] \\
\hline Ti/Ru alloy mesh plates & -1.8 & 20 & Sewage sludge & 1360 & [32] \\
\hline Carbon cloth + Pt & -0.8 & 162 & Waste activated sludge & 200 & [92] \\
\hline Fe tube + Graphite pillar & -0.3 & 45 & Waste activated sludge & 22 & [86] \\
\hline Graphite carbon + Ni & -0.3 & $\mathrm{ND}^{\mathrm{a}}$ & Food waste & 70 & [93] \\
\hline Titanium mesh & -0.3 & 40 & Glycerol & 60 & [3] \\
\hline Stainless steel & -0.8 & $\mathrm{ND}^{\mathrm{a}}$ & Glycose & 52 & [94] \\
\hline
\end{tabular}

It was reported that EV application could reduce the time for stabilizing reaction. However, this is not necessarily leading to higher $\mathrm{CH}_{4}$ yield. In this regard, Park group [93] treated highly concentrated food waste in AD reactor, where EV of $-0.3 \mathrm{~V}$ vs. SHE was applied. Expectedly, both stabilization time and $\mathrm{CH}_{4}$ production rate were accelerated by 4.0 and 1.7 times faster than control, respectively. However, the final $\mathrm{CH}_{4}$ production was the same for EV-supplemented reactor and control. Similarly, our research group treated phenol and could not observe significant difference in $\mathrm{CH}_{4}$ productivity between EV-applied UASB and control UASB, at low OLR $(<5.3 \mathrm{~kg}$ chemical oxygen demand (COD) $\left./ \mathrm{m}^{3} / \mathrm{d}\right)$. However, the significant impact was observed at higher OLRs [29]. Another research group highlighted that the electrode polarization could boost volumetric $\mathrm{CH}_{4}$ production and $\mathrm{CH}_{4}$ content by $53 \%$ and $20.6 \%$, respectively [19]. This implies that EV application can be the key for various merits in AD. The proposed mechanisms for the achieved enhancements under DIET-stimulated conditions were linked mainly to the increased abundance of EAB, along with methanogens, and the advanced electron transfer rate. The effective contribution to DIET enhancement seems to be more related to broth consortia than electrode biofilm, since the amount of $\mathrm{CH}_{4}$ released from electrodes was very limited, compared to that from the broth [3,27-29]. Specifically, $\mathrm{CH}_{4}$ generation from the electrodes was found to be lower than $5 \%$ of the total generated $\mathrm{CH}_{4}[3,29]$.

Generally, the required EV was decided by considering both electrode potential for $\mathrm{H}_{2}$ evolution, which differs based on the electrode material, and electrode potential at which the reduced products could be harvested $[95,96]$. For instance, when $\mathrm{CH}_{4}$ production was implemented using a pure culture of Methanobacterium-like archaeon, attached to graphite cathode, the selected EV was $-0.4 \mathrm{~V}$ vs. SHE [97]. Such EV was more positive than the potential for $\mathrm{H}_{2}$ generation using graphite as electrode material $[98,99]$. 
The effectiveness of BES-AD was found to be cardinally linked to the utilized electrode material. Generally, the utilized electrodes are required to have high particular characteristics, such as large surface area, electrochemical active surface, and acceptable electrical conductivity $[100,101]$. Further, biocompatibility and low cost are additional recommended characteristics [102]. Carbon materials seem to be the most utilized electrode material (Table 2). This might be because of carbon characteristics, e.g., low cost, high conductivity, good biocompatibility, and high capability for biofilm formation [103,104]. For enhancing the aforementioned features, carbon-based electrodes were modified by nano-sized particles of transition elements as (Co and P) [91], Pt [92], Fe [86], and Ni [93] (Table 2).

\section{Microbial Community Change after DIET Stimulation}

Generally, the most commonly studied DIET-implicated genera are Geobacter and Shewanella $[10,68,105]$. In their pioneering work, Summers et al. [10] observed DIET occurrence in a defined co-culture that consisted of G. metallireducens, as an exoelectrogenic bacteria, and G. sulfurreducens, a fumarate reducer. Later on, metatranscriptomic analysis was employed for confirming DIET occurrence between G. sulfurreducens and G. metallireducens, [106] or G. sulfurreducens and Methanothrix sp. [107]. These studies considered the limited abundance for hydrogenase and/or formate dehydrogenase transcript as strong indicator for DIET occurrence among the syntrophic partners. Further, DIET-capable syntrophic co-culture, which consisted of Methanosaeta sp. and Geobacter sp., was detected in BES-AD system [108].

In addition, the potential DIET occurrence was previously claimed between Geobacter sp. and acetoclastic methanogen (Methanosaeta sp.) [12], hydrogentrophic methanogen (Methanobacterium sp.) [7], or methanogen that can work as both acetoclastic and hydrogentrophic (Methanosarcina sp.) [50]. Apparently, various types of methanogens exhibited DIET capability. However, so far, there is no conclusion regarding which methanogen must be enriched as a result of DIET-stimulating condition, either by CM supplementation and/or EV application. For instance, when the low strength wastewater, which contained glucose as a main carbon source, was treated through BES system, equipped with graphene/polypyrrole electrode, hydrogentrophic methanogens' dominance was recorded [109]. However, the usage of nano-graphene for the treatment of the same wastewater could induce the presence of Methanosaeta sp. (acetoclastic methanogen) [110] (Table 4). Another informative example can be obtained through exploring the impact of ethanol, utilized as DIET stimulator, upon the syntrophic metabolism of propionate and butyrate [72]. Results exhibited that ethanol's presence enriched the abundance of Methanosarcina sp. and Methanosaeta sp., irrespective of whether the substrate was propionate or butyrate. However, in case of propionate, both of Methanosarcina sp. and Methanosaeta sp. could be enriched by almost the same ratio. On the other hand, when the substrate was propionate, ethanol's presence could mainly augment the abundance of Methanosarcina sp. [72]. Like the relation between the supplemented $\mathrm{CM}$ and enriched methanogens, the relation between the value of the applied EV and the type of methanogens that can be enriched is still unclear. In addition, the change in the composition of microbial community cannot directly refer to the active type of interspecies electron transfer [80]. Another unclear point is related to the electron receptors of enriched methanogens. Basically, there is an agreement that Geobacter sp. is exporting electrons through its conductive pili $[50,111,112]$; however, the mechanism by which electrons are received by methanogen is still vaguely understood [12]. 
Table 4. The enrichment of methanogenic consortia after direct interspecies electron transfer (DIET) stimulation.

\begin{tabular}{|c|c|c|c|c|}
\hline Main Carbon Source & DIET Stimulator & Enriched Methanogens & Metabolic & Reference \\
\hline Butyrate, propionate, and acetate & Magnetite nanoparticles & Methanobacterium sp. & Hydrogentrophic & [113] \\
\hline Glucose & $\begin{array}{l}\text { Bioelectrochemical system } \\
\text { with graphene/polypyrrole }\end{array}$ & Methanoregula sp. & Hydrogentrophic & [109] \\
\hline Food waste and Sewage sludge & Sawdust-derived biochar & Methanothermobacter sp. & Hydrogentrophic & [114] \\
\hline Glucose & Magnetite & Methanobacterium sp. & Hydrogentrophic & [7] \\
\hline Acetic acid & Granular active carbon & Methanospirillaceae sp. & Hydrogentrophic & [115] \\
\hline Glycerol & Magnetite & Methanomassiliicoccus sp. & Hydrogentrophic & [3] \\
\hline Swine manure & Granular active carbon & Methanosaeta sp. & Acetoclastic & [116] \\
\hline Glucose & Nano-graphene & Methanosaeta sp. & Acetoclastic & [110] \\
\hline Ethanol and glucose & Powered activated carbon & Methanosarcina sp. & Acetoclastic & [117] \\
\hline $\begin{array}{l}\text { Sodium acetate, sodium } \\
\text { propionate, and sodium butyrate }\end{array}$ & $\mathrm{TiO}_{2}$ nanoparticles & $\begin{array}{l}\text { Methanobacterium sp. } \\
\text { and Methanosarcina sp. }\end{array}$ & $\begin{array}{l}\text { Hydrogentrophic } \\
\text { and acetoclastic }\end{array}$ & [118] \\
\hline
\end{tabular}

In BES-AD studies, various species could be enriched, such as Methanococcus maripaludis [119] and Methanobacterium congolense [120]. The type of enriched consortia might be related to the utilized electrode and the utilized catalyst [121]. For instance, mixed culture of anaerobic consortia could have better respiration condition when stainless-steel was used as cathode, than that while using pure conventional carbon-based materials [122]. Further, microbial growth/colonization on the surface of the electrode is governed by the electrode surface properties since they affect microbes-electrode interaction, which depends upon the formed bond, e.g., Van der Waals force, hydrogen bonding, or electrostatic interaction [101]. For instance, a faster growth for biofilm could be achieved, when the utilized electrode material has a positive charge. This is because of microorganisms' negative charge [123]. Further, extra-porous and nano-sized materials are perfect scaffold for improved microbial attachment/growth, enhancing biofilm formation [124]. A point of debate is the impact of DIET stimulation upon microbial diversity; some researches confirmed diversity lowering, as a result of DIET stimulation $[29,125]$; however, other researches referred to increased microbial diversity under DIET-stimulated condition $[86,126]$.

Among the 11 studies shown in Table 2, only 4 research articles detected Geobacter sp. [47,48,57,59]. Furthermore, those four studies revealed very slight abundance for Geobacter sp. $(<5 \%$ of the total bacterial community detected). Previous review article also highlighted that most of the studies that claimed DIET occurrence could not detect Geobacter sp. [34]. This dilemma might have two possible explanations. Firstly, if the claimed DIET did not really happen, then the enhancements of $\mathrm{CH}_{4}$ productivity, in terms of yield and/or rate of production, might be assigned to other roles played by the utilized DIET-stimulator, such as enhancing biomass colonization [77-79] or stimulating organics' degrading microbes for enzymes' secretion and substrate utilization $[29,60]$. Secondly, if the claimed DIET really happened, then the applied DIET stimulation strategy could induce DIET-capable syntrophic bacteria, yet to be confirmed as EAB [34,127]. The latter explanation might agree with recent findings that confirmed DIET can be a common electron transfer option for not only Geobacter and Shewanella but also for various syntrophs such as Pelobacter sp. and Syntrophorhabdus sp., which are potential EAB [3,32]. Future studies need to confirm DIET capability/incapability of the detected species in DIET-stimulated reactors, in order to assure DIET occurrence; in addition, the enrichments in the abundance of other species, different from $\mathrm{EAB}$, must be involved in explaining $\mathrm{CH}_{4}$ productivity and substrate utilization efficiency profiles.

\section{Conclusions and Future Perspectives}

This review tried to give comprehensive explanation for the recent advanced knowledge regarding DIET, as an alternative metabolic approach for enhancing $\mathrm{CH}_{4}$ productivity from various wastes. DIET reaction could provide theoretically advantageous route due to its more negative value of $\Delta \mathrm{G}^{0}$, and there is no need for the generation and diffusion of metabolites. It could be stimulated through the supplementation of CM and/or the application of EV. CBCM could compensate the lack of Geobacter conductive pili, and IBCM could reduce the bacterial need for OmcS production. In applying EV, carbon 
was the commonly utilized electrode material, because of its high conductivity and low cost. The increased amount of $\mathrm{CH}_{4}$ production from the electrodes was negligible, indicating active DIET reaction occurring in the broth. DIET establishment leads to enriching acetoclastic and/or hydrogentrophic methanogens. Geobacter sp. was absent or slightly present in most of DIET studies that utilized mixed culture as inocula. Away from EAB, other bacterial species that are enriched after DIET stimulation might be implicated in the detected $\mathrm{CH}_{4}$ productivity improvements.

(a) Engineering perspectives

From an engineering perspective, the economic feasibility of DIET stimulation in AD reactors is still questionable. It can be roughly considered that the cost of CM supplementation, as DIET stimulation approach, might be lower than applying EV, which requires the installation of two electrodes that are recommended to be fabricated using CM. However, further studies need to be implemented in order to compare the economic feasibility of the two DIET stimulation approaches, considering the maintenance cost and CM loss during EV application and CM supplementation, respectively. For reducing the overall cost needed for DIET stimulation, two approaches are suggested. First approach is the usage of relatively cheap $\mathrm{CM}$, such as red mud, or to recover that $\mathrm{CM}$ from other wastes, e.g., biochar recovery from digestate by pyrolysis.

Second approach depends on DIET establishing through two steps: (i) ethanol-type fermentation of easily biodegradable substrate, such as polysaccharide and (ii) methanogenesis, where, the ethanol-rich effluent, obtained from the first step was utilized for providing better conditions for DIET stimulation in the second step. Such approach was based on the special favorability of DIET-implicated microorganisms to ethanol, as a substrate [128]. Zhao group denoted that sludge fed with ethanol had higher abundance for Methanothrix sp. and gene for pilA, compared to that when propionate and butyrate were used as feeds. This strategy caused increase in $\mathrm{CH}_{4}$ production from WAS by 36\% [129] and 30\% [130]. On the other hand, fabrication of electrodes that have low cost can support EV-based DIET performing. These perspectives can help in the commercialization of DIET-based reactors; however, more successful tests for bench-scale reactors are needed. In this regard, Yee et al. [131] provided a detailed practical protocol for the setting of the electrochemical reactors. Future tests have to consider calculating benefit/cost ratio for DIET-stimulated digestor and comparing it to control digestors. Thereafter, large scale application will just be an issue of time.

\section{(b) Scientific perspectives}

Undoubtedly, there is a literature chaos, specifically around CM-based DIET stimulation topic, since DIET occurrence has been claimed in many researches, without revealing vital experimental evidences. Therefore, recent review articles indicated that more experimental observations are required before claiming DIET stimulation [36,80]. Future researches should direct more effort for verifying DIET activation and/or other potential changes in anaerobic growth, which can be implicated in the observed enhancement in $\mathrm{CH}_{4}$ production rate and/or yield. Recently, Van Steendam et al. [132] evaluated some advanced DIET identification methods, including fluorescence in situ hybridization, cyclic voltammetry, scanning, transmission electron microscope, and various (meta-)omic approaches; the usage of combined methods for confirming DIET occurrence was finally recommended. Additionally, Neu et al. [133] presented temperature-resolved $\mathrm{THz}$ spectroscopy that can easily measure the conductivity of wild-type pili. Further, Yee et al. [131] explained some electrochemical techniques that can be utilized for determining the electroactivity and the mode of electron transfer during the reactions. The aforementioned studies are referring to the right track of research that is worthy to be followed. More studies are needed to describe strict and simple verification strategy for validating DIET occurrence/absence.

Since they have noticed the electric conductivity of syntrophic aggregates that contained Geobacter sp., Lovley's team explained the observed long-distance electron transfer based on e-pili, composed of PilA protein, which had metallic-like conductivity and could act as 
conduit $[10,21,22,134,135]$. However, a recent work by Wang et al. [136] gave proofs to indicate that the conduit for such long-distance electron exchange process is not e-pili, rather, it can be cytochrome OmcS, in its polymerized chain form. Wang's group concluded that the role played by PilA is stimulating the excretion of OmcS. This view around the mechanism of electron transfer needs further research to be established. From the way how the e-pili were formed, it seems that we need to understand more about the characteristics of those e-pili. Very recently, an astonishing research work proved that the protein nanowires that were harvested from G. sulfurreducens can form a thin-film device, which is able to generate continuous electric power ( $0.5 \mathrm{~V}$ across a $7 \mu \mathrm{m}$ thick film) in the ambient environment [137].

The rate of electron transfer seems to be one of the hot points that needs further experimental research and predictive models, since available information in literature about the efficiency and energetic losses, during DIET, are limited. Moreover, more models are needed to witness the response of microbial consortia to harsh environmental changes, and the mechanism of microbial cooperation for metabolism under such conditions. In other words, the question that needs to be answered is to what extent DIET can be the way for the best diet?

Author Contributions: Conceptualization: D.-H.K.; Writing-Original Draft Preparation: A.M. and S.I., Writing - Review \& Editing: D.-H.K., Y.-C.S. and Y.A.; Supervision: D.-H.K. All authors have read and agreed to the published version of the manuscript.

Funding: This work was supported by INHA UNIVERSITY Research Grant (INHA-61668-01).

Conflicts of Interest: The authors declare no conflict of interest.

\section{References}

1. Im, S.; Petersen, S.; Lee, D.; Kim, D. Effects of storage temperature on $\mathrm{CH}_{4}$ emissions from cattle manure and subsequent biogas production potential. Waste Manag. 2020, 101, 35-43. [CrossRef]

2. Shin, S.; Im, S.; Mostafa, A.; Lee, M.; Yun, Y.; Oh, S.; Kim, D. Effects of pig slurry acidification on methane emissions during storage and subsequent biogas production. Water Res. 2019, 152, 234-240. [CrossRef]

3. Im, S.; Yun, Y.; Song, Y.; Kim, D. Enhanced anaerobic digestion of glycerol by promoting DIET reaction. Biochem. Eng. J. 2019, 142, 18-26. [CrossRef]

4. Feng, Q.; Song, Y.; Kim, D.; Kim, M.; Kim, D. Influence of the temperature and hydraulic retention time in bioelectrochemical anaerobic digestion of sewage sludge. Int. J. Hydrog. Energy 2018, 44, 2170-2179. [CrossRef]

5. Shen, L.; Zhao, Q.; Wu, X.; Li, X.; Li, Q.; Wang, Y. Interspecies electron transfer in syntrophic methanogenic consortia: From cultures to bioreactors. Renew. Sustain. Energy Rev. 2016, 54, 1358-1367. [CrossRef]

6. Meslé, M.; Dromart, G.; Oger, P. Microbial methanogenesis in subsurface oil and coal. Res. Microbiol. 2013, 164, 959-972. [CrossRef]

7. Zhao, Z.; Li, Y.; Quan, X.; Zhang, Y. Towards engineering application: Potential mechanism for enhancing anaerobic digestion of complex organic waste with different types of conductive materials. Water Res. 2017, 115, 266-277. [CrossRef]

8. Cazier, E.; Trably, E.; Steyer, J.; Escudie, R. Reversibility of hydrolysis inhibition at high hydrogen partial pressure in dry anaerobic digestion processes fed with wheat straw and inoculated with anaerobic granular sludge. Waste Manag. 2019, 85, 498-505. [CrossRef]

9. Cazier, E.; Trably, E.; Steyer, J.; Escudie, R. Biomass hydrolysis inhibition at high hydrogen partial pressure in solid-state anaerobic digestion. Bioresour. Technol. 2015, 190, 106-113. [CrossRef]

10. Summers, Z.; Fogarty, H.; Leang, C.; Franks, A.; Malvankar, N.; Lovley, D. Direct exchange of electrons within aggregates of an evolved syntrophic coculture of anaerobic bacteria. Science 2010, 80, 819-824. [CrossRef]

11. Liu, X.; Shi, L.; Gu, J. Microbial electrocatalysis: Redox mediators responsible for extracellular electron transfer. Biotechnol. Adv. 2018, 36, 1815-1827. [CrossRef] 
12. Rotaru, A.; Shrestha, P.; Liu, F.; Shrestha, M.; Shrestha, D.; Embree, M.; Zengler, K.; Wardman, C.; Nevin, K.; Lovley, D. A new model for electron flow during anaerobic digestion: Direct interspecies electron transfer to Methanosaeta for the reduction of carbon dioxide to methane. Energy Environ. Sci. 2014, 7, 408-415. [CrossRef]

13. Xiao, L.; Liu, F.; Liu, J.; Li, J.; Zhang, Y.; Yu, J.; Wang, O. Nano-Fe ${ }_{3} \mathrm{O}_{4}$ particles accelerating electromethanogenesis on an hour-long timescale in wetland soil. Environ. Sci. Nano 2018, 5, 436-445. [CrossRef]

14. Zhang, J.; Lu, Y. Conductive $\mathrm{Fe}_{3} \mathrm{O}_{4}$ nanoparticles accelerate syntrophic methane production from butyrate oxidation in two different lake sediments. Front. Microbiol. 2016, 7, 1-9. [CrossRef]

15. Zhang, W.; Zhang, J.; Lu, Y. Stimulation of carbon nanomaterials on syntrophic oxidation of butyrate in sediment enrichments and a defined coculture. Sci. Rep. 2018, 8, 1-13. [CrossRef]

16. Li, H.; Chang, J.; Liu, P.; Fu, L.; Ding, D.; Lu, Y. Direct interspecies electron transfer accelerates syntrophic oxidation of butyrate in paddy soil enrichments. Environ. Microbiol. 2015, 17, 1533-1547. [CrossRef]

17. Ye, J.; Hu, A.; Ren, G.; Chen, M.; Tang, J.; Zhang, P.; Zhou, S.; He, Z. Enhancing sludge methanogenesis with improved redox activity of extracellular polymeric substances by hematite in red mud. Water Res. 2018, 134, 54-62. [CrossRef]

18. Piao, D.; Song, Y.; Kim, D. Bioelectrochemical enhancement of biogenic methane conversion of coal. Energies 2018, 11, 2577. [CrossRef]

19. Feng, Q.; Song, Y.; Yoo, K.; Kuppanan, N.; Subudhi, S.; Lal, B. Polarized electrode enhances biological direct interspecies electron transfer for methane production in upflow anaerobic bioelectrochemical reactor. Chemosphere 2018, 204, 186-192. [CrossRef]

20. Kato, S.; Hashimoto, K.; Watanabe, K. Methanogenesis facilitated by electric syntrophy via (semi)conductive iron-oxide minerals. Environ. Microbiol. 2012, 14, 1646-1654. [CrossRef]

21. Lovley, D.; Walker, D. Geobacter protein nanowires. Front. Microbiol. 2019, 10, 2078. [CrossRef]

22. Ueki, T.; Walker, D.; Tremblay, P.; Nevin, K.; Ward, J.; Woodard, T.; Nonnenmann, S.; Lovley, D. Decorating the outer surface of microbially produced protein nanowires with peptides. ACS Synth. Biol. 2019, 8, 1809-1817. [CrossRef]

23. Malvankar, N.; Lovley, D. Microbial nanowires for bioenergy applications. Curr. Opin. Biotechnol. 2014, 27, 88-95. [CrossRef]

24. Tan, Y.; Adhikari, R.; Malvankar, N.; Ward, J.; Nevin, K.; Woodard, T.; Smith, J.; Snoeyenbos-West, O.; Franks, A.; Tuominen, M.; et al. The low conductivity of Geobacter uraniireducens pili suggests a diversity of extracellular electron transfer mechanisms in the genus Geobacter. Front. Microbiol. 2016, 7, 1-10. [CrossRef]

25. Liu, F.; Rotaru, A.; Shrestha, P.; Malvankar, N.; Nevin, K.; Lovley, D. Magnetite compensates for the lack of a pilin-associated c-type cytochrome in extracellular electron exchange. Environ. Microbiol. 2015, 17, 648-655. [CrossRef]

26. Li, J.; Xiao, L.; Zheng, S.; Zhang, Y.; Luo, M.; Tong, C.; Xu, H.; Tan, Y.; Liu, J.; Wang, O.; et al. A new insight into the strategy for methane production affected by conductive carbon cloth in wetland soil: Beneficial to acetoclastic methanogenesis instead of $\mathrm{CO}_{2}$ reduction. Sci. Total Environ. 2018, 643, 1024-1030. [CrossRef]

27. Song, Y.; Joicy, A.; Jang, S. Direct interspecies electron transfer in bulk solution significantly contributes to bioelectrochemical nitrogen removal. Int. J. Hydrog. Energy 2018, 44, 1-11. [CrossRef]

28. Feng, Q.; Song, Y.; Yoo, K.; Kuppanan, N.; Subudhi, S.; Lal, B. Bioelectrochemical enhancement of direct interspecies electron transfer in upflow anaerobic reactor with effluent recirculation for acidic distillery wastewater. Bioresour. Technol. 2017, 241, 171-180. [CrossRef]

29. Mostafa, A.; Im, S.; Lee, M.; Song, Y.; Kim, D. Enhanced anaerobic digestion of phenol via electrical energy input. Chem. Eng. J. 2020, 389, 124501. [CrossRef]

30. Ahn, Y.; Im, S.; Chung, J. Optimizing the operating temperature for microbial electrolysis cell treating sewage sludge. Int. J. Hydrog. Energy 2017, 42, 27784-27791. [CrossRef]

31. Cheng, S.; Hamelers, H. Critical review microbial electrolysis cells for high yield hydrogen gas production from organic matter. Environ. Sci. Technol. 2008, 42, 8630-8640.

32. Guo, X.; Liu, J.; Xiao, B. Bioelectrochemical enhancement of hydrogen and methane production from the anaerobic digestion of sewage sludge in single-chamber membrane-free microbial electrolysis cells. Int. J. Hydrog. Energy 2013, 38, 1342-1347. [CrossRef] 
33. Kyazze, G.; Popov, A.; Dinsdale, R.; Esteves, S.; Hawkes, F.; Premier, G.; Guwy, A. Influence of catholyte pH and temperature on hydrogen production from acetate using a two chamber concentric tubular microbial electrolysis cell. Int. J. Hydrog. Energy 2010, 35, 7716-7722. [CrossRef]

34. Yin, Q.; Wu, G. Advances in direct interspecies electron transfer and conductive materials: Electron flux, organic degradation and microbial interaction. Biotechnol. Adv. 2019, 37, 107443. [CrossRef]

35. Baek, G.; Kim, J.; Kim, J.; Lee, C. Role and potential of direct interspecies electron transfer in anaerobic digestion. Energies 2018, 11, 107. [CrossRef]

36. Baniamerian, H.; Isfahani, P.G.; Tsapekos, P.; Alvarado-Morales, M.; Shahrokhi, M.; Vossoughi, M.; Angelidaki, I. Application of nano-structured materials in anaerobic digestion: Current status and perspectives. Chemosphere 2019, 229, 188-199. [CrossRef]

37. Baek, G.; Kim, J.; Lee, C. A review of the effects of iron compounds on methanogenesis in anaerobic environments. Renew. Sustain. Energy Rev. 2019, 113, 109282. [CrossRef]

38. Lovley, D.R. Reach out and touch someone: Potential impact of DIET (direct interspecies energy transfer) on anaerobic biogeochemistry, bioremediation, and bioenergy. Rev. Environ. Sci. Biotechnol. 2011, 10, 101-105. [CrossRef]

39. Viggi, C.; Rossetti, S.; Fazi, S.; Paiano, P.; Majone, M.; Aulenta, F. Magnetite particles triggering a faster and more robust syntrophic pathway of methanogenic propionate degradation. Environ. Sci. Technol. 2014, 48, 7536-7543. [CrossRef]

40. Cheng, Q.; Call, D. Hardwiring microbes: Via direct interspecies electron transfer: Mechanisms and applications. Environ. Sci. Process. Impacts 2016, 18, 968-980. [CrossRef]

41. Storck, T.; Virdis, B.; Batstone, D. Modelling extracellular limitations for mediated versus direct interspecies electron transfer. ISME J. 2016, 10, 621-631. [CrossRef]

42. Lovley, D. Happy together: Microbial communities that hook up to swap electrons. ISME J. 2017, 11, 327-336. [CrossRef]

43. Mostafa, A.; Im, S.; Song, Y.; Kang, S.; Kim, D. Enhanced anaerobic digestion of long chain fatty acid by adding magnetite and carbon nanotubes. Microorganisms 2020, 8, 333. [CrossRef]

44. Zhang, Y.; Li, J.; Liu, F.; Yan, H.; Li, J.; Zhang, X. Reduction of Gibbs free energy and enhancement of Methanosaeta by bicarbonate to promote anaerobic syntrophic butyrate oxidation. Bioresour. Technol. 2018, 267, 209-217. [CrossRef]

45. Zhao, Z.; Zhang, Y.; Li, Y.; Dang, Y.; Zhu, T.; Quan, X. Potentially shifting from interspecies hydrogen transfer to direct interspecies electron transfer for syntrophic metabolism to resist acidic impact with conductive carbon cloth. Chem. Eng. J. 2017, 313, 10-18. [CrossRef]

46. Feng, Q.; Song, Y.; Yoo, K.; Kuppanan, N.; Subudhi, S.; Lal, B. Influence of neutralization in acidic distillery wastewater on direct interspecies electron transfer for methane production in an upflow anaerobic bioelectrochemical reactor. Int. J. Hydrog. Energy 2017, 42, 27774-27783. [CrossRef]

47. Li, Y.; Zhang, Y.; Yang, Y.; Quan, X.; Zhao, Z. Potentially direct interspecies electron transfer of methanogenesis for syntrophic metabolism under sulfate reducing conditions with stainless steel. Bioresour. Technol. 2017, 234, 303-309. [CrossRef]

48. Zhuang, L.; Ma, J.; Yu, Z.; Wang, Y.; Tang, J. Magnetite accelerates syntrophic acetate oxidation in methanogenic systems with high ammonia concentrations. Microb. Biotechnol. 2018, 11, 710-720. [CrossRef]

49. Liu, F.; Rotaru, A.; Shrestha, P.; Malvankar, N.; Nevin, K.; Lovley, D. Promoting direct interspecies electron transfer with activated carbon. Energy Environ. Sci. 2012, 5, 8982-8989. [CrossRef]

50. Rotaru, A.; Shrestha, P.; Liu, F.; Markovaite, B.; Chen, S.; Nevin, K.; Lovley, D. Direct interspecies electron transfer between Geobacter metallireducens and Methanosarcina barkeri. Appl. Environ. Microbiol. 2014, 80, 4599-4605. [CrossRef]

51. Chen, S.; Rotaru, A.; Liu, F.; Philips, J.; Woodard, T.; Nevin, K.; Lovley, D. Carbon cloth stimulates direct interspecies electron transfer in syntrophic co-cultures. Bioresour. Technol. 2014, 173, 82-86. [CrossRef]

52. Chen, S.; Rotaru, A.; Shrestha, P.; Malvankar, N.; Liu, F.; Fan, W.; Nevin, K.; Lovley, D. Promoting interspecies electron transfer with biochar. Sci. Rep. 2014, 4, 5019. [CrossRef] 
53. Zhang, S.; Chang, J.; Lin, C.; Pan, Y.; Cui, K.; Zhang, X.; Liang, P.; Huang, X. Enhancement of methanogenesis via direct interspecies electron transfer between Geobacteraceae and Methanosaetaceae conducted by granular activated carbon. Bioresour. Technol. 2017, 245, 132-137. [CrossRef] [PubMed]

54. Ueki, T.; Nevin, K.; Rotaru, A.; Wang, L.; Ward, J.; Woodard, T.; Lovley, D. Geobacter strains expressing poorly conductive pili reveal constraints on direct interspecies electron transfer mechanisms. mBio 2018, 9, 1-10. [CrossRef]

55. Yan, W.; Shen, N.; Xiao, Y.; Chen, Y.; Sun, F.; Kumar Tyagi, V.; Zhou, Y. The role of conductive materials in the start-up period of thermophilic anaerobic system. Bioresour. Technol. 2017, 239, 336-344. [CrossRef]

56. Yan, W.; Lu, D.; Liu, J.; Zhou, Y. The interactive effects of ammonia and carbon nanotube on anaerobic digestion. Chem. Eng. J. 2019, 372, 332-340. [CrossRef]

57. Ye, J.; Hu, A.; Ren, G.; Zhou, T.; Zhang, G.; Zhou, S. Red mud enhances methanogenesis with the simultaneous improvement of hydrolysis-acidification and electrical conductivity. Bioresour. Technol. 2018, 247, 131-137. [CrossRef]

58. Baek, G.; Kim, J.; Cho, K.; Bae, H.; Lee, C. The biostimulation of anaerobic digestion with (semi) conductive ferric oxides: Their potential for enhanced biomethanation. Environ. Biotechnol. 2015, 99, 10355-10366. [CrossRef]

59. Pérez, C.; DeGrandpre, M.; Lagos, N.; Saldías, G.; Cascales, E.; Vargas, C. Effect of ferrihydrite biomineralization on methanogenesis in an anaerobic incubation from paddy soil. J. Geophys. Res. Biogeosci. 2015, 120, 673-692. [CrossRef]

60. Jing, Y.; Wan, J.; Angelidaki, I.; Zhang, S.; Luo, G. iTRAQ quantitative proteomic analysis reveals the pathways for methanation of propionate facilitated by magnetite. Water Res. 2017, 108, 212-221. [CrossRef]

61. Yamada, C.; Kato, S.; Ueno, Y.; Ishii, M.; Igarashi, Y. Conductive iron oxides accelerate thermophilic methanogenesis from acetate and propionate. J. Biosci. Bioeng. 2015, 119, 678-682. [CrossRef] [PubMed]

62. Baek, G.; Kim, J.; Lee, C. A long-term study on the effect of magnetite supplementation in continuous anaerobic digestion of dairy effluent-Enhancement in process performance and stability. Bioresour. Technol. 2016, 222, 344-354. [CrossRef]

63. Li, L.; Tong, Z.; Fang, C.; Chu, J.; Yu, H. Response of anaerobic granular sludge to single-wall carbon nanotube exposure. Water Res. 2015, 70, 1-8. [CrossRef]

64. Ambuchi, J.; Zhang, Z.; Shan, L.; Liang, D.; Zhang, P.; Feng, Y. Response of anaerobic granular sludge to iron oxide nanoparticles and multi-wall carbon nanotubes during beet sugar industrial wastewater treatment. Water Res. 2017, 117, 87-94. [CrossRef]

65. Dang, Y.; Holmes, D.; Zhao, Z.; Woodard, T.; Zhang, Y.; Sun, D.; Wang, L.; Nevin, K.; Lovley, D. Enhancing anaerobic digestion of complex organic waste with carbon-based conductive materials. Bioresour. Technol. 2016, 220, 516-522. [CrossRef]

66. Dang, Y.; Sun, D.; Woodard, T.; Wang, L.; Nevin, K.; Holmes, D. Stimulation of the anaerobic digestion of the dry organic fraction of municipal solid waste (OFMSW) with carbon-based conductive materials. Bioresour. Technol. 2017, 238, 30-38. [CrossRef] [PubMed]

67. Lei, Y.; Sun, D.; Dang, Y.; Chen, H.; Zhao, Z.; Zhang, Y.; Holmes, D. Stimulation of methanogenesis in anaerobic digesters treating leachate from a municipal solid waste incineration plant with carbon cloth. Bioresour. Technol. 2016, 222, 270-276. [CrossRef] [PubMed]

68. Lovley, D. Syntrophy goes electric: Direct interspecies electron transfer. Annu. Rev. Microbiol. 2017, 71, 643-664. [CrossRef]

69. Zhao, Z.; Zhang, Y.; Woodard, T.; Nevin, K.; Lovley, D. Enhancing syntrophic metabolism in up-flow anaerobic sludge blanket reactors with conductive carbon materials. Bioresour. Technol. 2015, 191, 140-145. [CrossRef]

70. Barua, S.; Dhar, B. Advances towards understanding and engineering direct interspecies electron transfer in anaerobic digestion. Bioresour. Technol. 2017, 244, 698-707. [CrossRef]

71. Shen, Y.; Linville, J.; Urgun-Demirtas, M.; Schoene, R.; Snyder, S. Producing pipeline-quality biomethane via anaerobic digestion of sludge amended with corn stover biochar with in-situ $\mathrm{CO}_{2}$ removal. Appl. Energy 2015, 158, 300-309. [CrossRef]

72. Zhao, Z.; Zhang, Y.; Yu, Q.; Dang, Y.; Li, Y.; Quan, X. Communities stimulated with ethanol to perform direct interspecies electron transfer for syntrophic metabolism of propionate and butyrate. Water Res. 2016, 102, 475-484. [CrossRef] 
73. Salvador, A.; Martins, G.; Melle-franco, M.; Serpa, R.; Stams, A.; Cavaleiro, A.; Pereira, M.; Alves, M. Carbon nanotubes accelerate methane production in pure cultures of methanogens and in a syntrophic coculture. Environ. Microbiol. 2017, 19, 2727-2739. [CrossRef]

74. Hirano, S.; Matsumoto, N.; Morita, M.; Sasaki, K.; Ohmura, N. Electrochemical control of redox potential affects methanogenesis of the hydrogenotrophic methanogen Methanothermobacter thermautotrophicus. Lett. Appl. Microbiol. 2013, 56, 315-321. [CrossRef]

75. Gu, M.; Yin, Q.; Liu, Y.; Du, J.; Wu, G. New insights into the effect of direct interspecies electron transfer on syntrophic methanogenesis through thermodynamic analysis. Bioresour. Technol. Rep. 2019, 7, 100225. [CrossRef]

76. Ishii, S.; Suzuki, S.; Tenney, A.; Nealson, K.; Bretschger, O. Comparative metatranscriptomics reveals extracellular electron transfer pathways conferring microbial adaptivity to surface redox potential changes. ISME J. 2018, 12, 2844-2863. [CrossRef]

77. Ammar, Y.; Swailes, D.; Bridgens, B.; Chen, J. Influence of surface roughness on the initial formation of biofilm. Surf. Coat. Technol. 2015, 284, 410-416. [CrossRef]

78. Medilanski, E.; Kaufmann, K.; Wick, L.Y.; Wanner, O.; Harms, H. Influence of the surface topography of stainless steel on bacterial adhesion. Biofouling 2002, 18, 193-203. [CrossRef]

79. Habouzit, F.; Gévaudan, G.; Hamelin, J.; Steyer, J.; Bernet, N. Influence of support material properties on the potential selection of Archaea during initial adhesion of a methanogenic consortium. Bioresour. Technol. 2011, 102, 4054-4060. [CrossRef]

80. Martins, G.; Salvador, A.; Pereira, L.; Alves, M. Methane production and conductive materials: A critical review. Environ. Sci. Technol. 2018, 52, 10241-10253. [CrossRef]

81. Yang, Z.; Guo, R.; Shi, X.; Wang, C.; Wang, L.; Dai, M. Magnetite nanoparticles enable a rapid conversion of volatile fatty acids to methane. RSC Adv. 2016, 6, 25662-25668. [CrossRef]

82. Kondaveeti, S.; Min, B. Bioelectrochemical reduction of volatile fatty acids in anaerobic digestion effluent for the production of biofuels. Water Res. 2015, 87, 137-144. [CrossRef] [PubMed]

83. Choi, O.; Sang, B.I. Extracellular electron transfer from cathode to microbes: Application for biofuel production. Biotechnol. Biofuels 2016, 9, 1-14. [CrossRef] [PubMed]

84. Lee, M.; Reddy, C.; Min, B. In situ integration of microbial electrochemical systems into anaerobic digestion to improve methane fermentation at different substrate concentrations. Int. J. Hydrog. Energy 2018, 44, 2-11. [CrossRef]

85. Lee, B.; Park, J.G.; Shin, W.B.; Tian, D.J.; Jun, H.B. Microbial communities change in an anaerobic digestion after application of microbial electrolysis cells. Bioresour. Technol. 2017, 234, 273-280. [CrossRef]

86. Feng, Y.; Zhang, Y.; Chen, S.; Quan, X. Enhanced production of methane from waste activated sludge by the combination of high-solid anaerobic digestion and microbial electrolysis cell with iron-graphite electrode. Chem. Eng. J. 2015, 259, 787-794. [CrossRef]

87. Linji, X.; Wenzong, L.; Yining, W.; Aijie, W.; Shuai, L.; Wei, J. Optimizing external voltage for enhanced energy recovery from sludge fermentation liquid in microbial electrolysis cell. Int. J. Hydrog. Energy 2013, 38, 15801-15806. [CrossRef]

88. Choi, K.; Kondaveeti, S.; Min, B. Bioelectrochemical methane $\left(\mathrm{CH}_{4}\right)$ production in anaerobic digestion at different supplemental voltages. Bioresour. Technol. 2017, 245, 826-832. [CrossRef]

89. De Vrieze, J.; Gildemyn, S.; Arends, J.; Vanwonterghem, I.; Verbeken, K.; Boon, N.; Verstraete, W.; Tyson, G.; Hennebel, T.; Rabaey, K. Biomass retention on electrodes rather than electrical current enhances stability in anaerobic digestion. Water Res. 2014, 54, 211-221. [CrossRef]

90. Choi, J.; Lee, C. Bioelectrochemical enhancement of methane production in anaerobic digestion of food waste. Int. J. Hydrog. Energy 2018, 44, 1-10. [CrossRef]

91. Hagos, K.; Liu, C.; Lu, X. Effect of endogenous hydrogen utilization on improved methane production in an integrated microbial electrolysis cell and anaerobic digestion: Employing catalyzed stainless steel mesh cathode. Chin. J. Chem. Eng. 2018, 26, 574-582. [CrossRef]

92. Liu, W.; Cai, W.; Guo, Z.; Wang, L.; Yang, C.; Varrone, C.; Wang, A. Microbial electrolysis contribution to anaerobic digestion of waste activated sludge, leading to accelerated methane production. Renew. Energy 2016, 91, 334-339. [CrossRef] 
93. Park, J.; Lee, B.; Tian, D.; Jun, H. Bioelectrochemical enhancement of methane production from highly concentrated food waste in a combined anaerobic digester and microbial electrolysis cell. Bioresour. Technol. 2018, 247, 226-233. [CrossRef] [PubMed]

94. Cai, W.; Han, T.; Guo, Z.; Varrone, C.; Wang, A.; Liu, W. Methane production enhancement by an independent cathode in integrated anaerobic reactor with microbial electrolysis. Bioresour. Technol. 2016, 208, 13-18. [CrossRef] [PubMed]

95. Noori, M.; Vu, M.; Ali, R.; Min, B. Recent advances in cathode materials and configurations for upgrading methane in bioelectrochemical systems integrated with anaerobic digestion. Chem. Eng. J. 2019, 123689. [CrossRef]

96. Deutzmann, J.; Sahin, M.; Spormann, A. Extracellular enzymes facilitate electron uptake in biocorrosion and bioelectrosynthesis. mBio 2015, 6, 1-8. [CrossRef] [PubMed]

97. Beese-Vasbender, P.; Grote, J.; Garrelfs, J.; Stratmann, M.; Mayrhofer, K. Selective microbial electrosynthesis of methane by a pure culture of a marine lithoautotrophic archaeon. Bioelectrochemistry 2015, 102, 50-55. [CrossRef]

98. Gregory, K.; Bond, D.; Lovley, D. Graphite electrodes as electron donors for anaerobic respiration. Environ. Microbiol. 2004, 6, 596-604. [CrossRef]

99. Thrash, J.; Coates, J. Review: Direct and indirect electrical stimulation of microbial metabolism. Environ. Sci. Technol. 2008, 42, 3921-3931. [CrossRef]

100. Wei, J.; Liang, P.; Huang, X. Recent progress in electrodes for microbial fuel cells. Bioresour. Technol. 2011, 102, 9335-9344. [CrossRef]

101. Guo, K.; Prévoteau, A.; Patil, S.; Rabaey, K. Engineering electrodes for microbial electrocatalysis. Curr. Opin. Biotechnol. 2015, 33, 149-156. [CrossRef] [PubMed]

102. Nelabhotla, A.; Dinamarca, $\mathrm{C}$. Bioelectrochemical $\mathrm{CO}_{2}$ reduction to methane: MES integration in biogas production processes. Appl. Sci. 2019, 9, 1056. [CrossRef]

103. Li, S.; Cheng, C.; Thomas, A. Carbon-based microbial-fuel-cell electrodes: From conductive supports to active catalysts. Adv. Mater. 2016, 29. [CrossRef] [PubMed]

104. Yee, M.; Snoeyenbos-west, O.; Thamdrup, B.; Ottosen, L.; Rotaru, A. Extracellular electron uptake by two methanosarcina species. Front. Energy Res. 2019, 7, 1-10. [CrossRef]

105. Kouzuma, A.; Kato, S.; Watanabe, K. Microbial interspecies interactions: Recent findings in syntrophic consortia. Front. Microbiol. 2015, 6, 1-8. [CrossRef] [PubMed]

106. Shrestha, P.; Rotaru, A.; Summers, Z.; Shrestha, M.; Liu, F.; Lovley, D. Transcriptomic and genetic analysis of direct interspecies electron transfer. Appl. Environ. Microbiol. 2013, 79, 2397-2404. [CrossRef]

107. Rice, M.; Soils, P.; Holmes, D.; Shrestha, P.; Walker, D.; Dang, Y.; Nevin, K.; Woodard, T.; Lovley, D. Metatranscriptomic evidence for direct interspecies electron transfer between Geobacter and Methanothrix species in methanogenic rice paddy soils. Appl. Environ. Microbiol. 2017, 83, 1-11.

108. Zhao, Z.; Zhang, Y.; Wang, L.; Quan, X. Potential for direct interspecies electron transfer in an electricanaerobic system to increase methane production from sludge digestion. Sci. Rep. 2015, 5, 1-12. [CrossRef]

109. Tian, T.; Qiao, S.; Yu, C.; Yang, Y.; Zhou, J. Low-temperature anaerobic digestion enhanced by bioelectrochemical systems equipped with graphene/PPy- and $\mathrm{MnO}_{2}$ nanoparticles/PPy-modified electrodes. Chemosphere 2019, 218, 119-127. [CrossRef]

110. Tian, T.; Qiao, S.; Li, X.; Zhang, M.; Zhou, J. Nano-graphene induced positive effects on methanogenesis in anaerobic digestion. Bioresour. Technol. 2017, 224, 41-47. [CrossRef]

111. Ziels, R.; Nobu, M.; Sousa, D. Elucidating syntrophic butyrate-degrading populations in anaerobic digesters using stable isotope-informed genome-resolved metagenomics. Msystems 2019, 4, 563387. [CrossRef] [PubMed]

112. Mei, R.; Nobu, M.; Narihiro, T.; Yu, J.; Sathyagal, A.; Willman, E.; Liu, W. Novel Geobacter species and diverse methanogens contribute to enhanced methane production in media-added methanogenic reactors. Water Res. 2018, 147, 403-412. [CrossRef]

113. Cruz Viggi, C.; Casale, S.; Chouchane, H.; Askri, R.; Fazi, S.; Cherif, A.; Zeppilli, M.; Aulenta, F. Magnetite nanoparticles enhance the bioelectrochemical treatment of municipal sewage by facilitating the syntrophic oxidation of volatile fatty acids. J. Chem. Technol. Biotechnol. 2019, 94, 3134-3146. [CrossRef] 
114. Wang, G.; Li, Q.; Gao, X.; Wang, X. Sawdust-derived biochar much mitigates VFAs accumulation and improves microbial activities to enhance methane production in thermophilic anaerobic digestion. ACS Sustain. Chem. Eng. 2018, 7, 2141-2150. [CrossRef]

115. Lee, J.; Lee, S.; Park, H. Enrichment of specific electro-active microorganisms and enhancement of methane production by adding granular activated carbon in anaerobic reactors. Bioresour. Technol. 2016, 205, 205-212. [CrossRef] [PubMed]

116. Xiao, Y.; Yang, H.; Yang, H.; Wang, H.; Zheng, D.; Liu, Y.; Pu, X.; Deng, L. Improved biogas production of dry anaerobic digestion of swine manure. Bioresour. Technol. 2019, 294, 122188. [CrossRef] [PubMed]

117. Xu, S.; Han, R.; Zhang, Y.; He, C.; Liu, H. Differentiated stimulating effects of activated carbon on methanogenic degradation of acetate, propionate and butyrate. Waste Manag. 2018, 76, 394-403. [CrossRef]

118. Ma, W.; Li, H.; Zhang, W.; Shen, C.; Wang, L.; Li, Y.; Li, Q.; Wang, Y. $\mathrm{TiO}_{2}$ nanoparticles accelerate methanogenesis in mangrove wetlands sediment. Sci. Total Environ. 2020, 713, 136602. [CrossRef]

119. Lohner, S.; Deutzmann, J.; Logan, B.; Leigh, J.; Spormann, A. Hydrogenase-independent uptake and metabolism of electrons by the archaeon Methanococcus maripaludis. ISME J. 2014, 8, 1673-1681. [CrossRef]

120. Mayer, F.; Enzmann, F.; Lopez, A.; Holtmann, D. Performance of different methanogenic species for the microbial electrosynthesis of methane from carbon dioxide. Bioresour. Technol. 2019, 289, 121706. [CrossRef]

121. Kracke, F.; Wong, A.B.; Maegaard, K.; Deutzmann, J.; Hubert, M.; Hahn, C.; Jaramillo, T.; Spormann, A. Robust and biocompatible catalysts for efficient hydrogen-driven microbial electrosynthesis. Commun. Chem. 2019, 2, 1-9. [CrossRef]

122. Ketep, S.; Bergel, A.; Calmet, A.; Erable, B. Stainless steel foam increases the current produced by microbial bioanodes in bioelectrochemical systems. Energy Environ. Sci. 2014, 7, 1633-1637. [CrossRef]

123. Zhang, T.; Nie, H.; Bain, T.; Lu, H.; Cui, M.; Snoeyenbos-West, O.; Franks, A.; Nevin, K.; Russell, T.; Lovley, D. Improved cathode materials for microbial electrosynthesis. Energy Environ. Sci. 2013, 6, 217-224. [CrossRef]

124. Du, J.; Catania, C.; Bazan, G.; Du, J.; Catania, C.; Bazan, G. Modification of abiotic-biotic interfaces with small molecules and nanomaterials for improved bioelectronics modification of abiotic-biotic interfaces with small molecules and nanomaterials for improved bioelectronics. Chem. Mater. 2013, 26, 686-697. [CrossRef]

125. Guo, Z.; Gao, L.; Wang, L.; Liu, W.; Wang, A. Enhanced methane recovery and exoelectrogen-methanogen evolution from low-strength wastewater in an up-flow bio film reactor with conductive granular graphite fillers. Front. Environ. Sci. Eng. 2018, 12, 13. [CrossRef]

126. Cerrillo, M.; Viñas, M.; Bonmatí, A. Unravelling the active microbial community in a thermophilic anaerobic digester-microbial electrolysis cell coupled system under different conditions. Water Res. 2017, 110, 192-201. [CrossRef]

127. Xu, S.; He, C.; Luo, L.; Lü, F.; He, P.; Cui, L. Comparing activated carbon of different particle sizes on enhancing methane generation in upflow anaerobic digester. Bioresour. Technol. 2015, 196, 606-612. [CrossRef]

128. Zhao, Z.; Wang, J.; Li, Y.; Zhu, T.; Yu, Q.; Wang, T.; Liang, S.; Zhang, Y. Why do DIETers like drinking: Metagenomic analysis for methane and energy metabolism during anaerobic digestion with ethanol. Water Res. 2019, 171, 115425. [CrossRef]

129. Zhu, Y.; Zhao, Z.; Zhang, Y. Using straw as a bio-ethanol source to promote anaerobic digestion of waste activated sludge. Bioresour. Technol. 2019, 286, 121388. [CrossRef]

130. Zhao, Z.; Li, Y.; He, J.; Zhang, Y. Establishing direct interspecies electron transfer during laboratory-scale anaerobic digestion of waste activated sludge via biological ethanol-type fermentation pretreatment. ACS Sustain. Chem. Eng. 2018, 6, 13066-13077. [CrossRef]

131. Yee, M.; Deutzmann, J.; Spormann, A.; Rotaru, A. Cultivating electroactive microbes-From field to bench. Nanotechnology 2020, 31, 1-46. [CrossRef] [PubMed]

132. Van Steendam, C.; Smets, I.; Skerlos, S.; Raskin, L. Improving anaerobic digestion via direct interspecies electron transfer requires development of suitable characterization methods. Curr. Opin. Biotechnol. 2019, 57, 183-190. [CrossRef] [PubMed]

133. Neu, J.; Yi, S.; Gu, Y.; O’Brien, J.; Srikanth, V.; Vu, D.; Schmuttenmaer, C.; Malvankar, N. Terahertz-conductivity in biological nanowire-networks. In Proceedings of the 44th International Conference on Infrared, Millimeter, and Terahertz Waves (IRMMW-THz), Paris, France, 1-6 September 2019; pp. 1-2.

134. Malvankar, N.; Vargas, M.; Nevin, K.; Franks, A.; Leang, C.; Kim, B.; Inoue, K.; Mester, T.; Covalla, S.; Johnson, J.; et al. Tunable metallic-like conductivity in microbial nanowire networks. Nat. Nanotechnol. 2011, 6, 573-579. [CrossRef] 
135. Shrestha, P.; Rotaru, A.; Comolli, L.; Berkeley, L. Plugging in or going wireless: Strategies for interspecies electron transfer. Front. Microbiol. 2014, 5, 1-8. [CrossRef] [PubMed]

136. Wang, F.; Gu, Y.; O’Brien, J.; Yi, S.; Yalcin, S.; Srikanth, V.; Shen, C.; Vu, D.; Ing, N.; Hochbaum, A.; et al. Structure of microbial nanowires reveals stacked hemes that transport electrons over micrometers. Cell 2019, 177, 361-369. [CrossRef] [PubMed]

137. Liu, X.; Gao, H.; Ward, J.; Xiaorong, L.; Yin, B.; Fu, T.; Chen, J.; Lovley, D.; Yao, J. Power generation from ambient humidity using protein nanowires. Nature 2020, 577, 1-5. [CrossRef]

(C) 2020 by the authors. Licensee MDPI, Basel, Switzerland. This article is an open access article distributed under the terms and conditions of the Creative Commons Attribution (CC BY) license (http://creativecommons.org/licenses/by/4.0/). 